\title{
An Empirical Examination of Elite Athletes' Stress Factors During Joining in the Training Center Program
}

Heny Setyawati ${ }^{1}$, Tandiyo Rahayu ${ }^{2}$, Nur Haziyanti binti Mohamad Khalid ${ }^{3}$, Didik Rinan Sumekto ${ }^{4}$

\footnotetext{
1 Semarang State University, Physical Education Department, F1 Building, Sekaran, Semarang, Indonesia, henysetyawati@mail.unnes.ac.id

2 Semarang State University, Physical Education Department, F1 Building, Sekaran, Semarang, Indonesia, tandiyorahayu@mail.unnes.ac.id

3 Sultan Idris Education University, Sport Science \& Coaching Department, Jalan Slim, MY- 35900 Tanjong Malim, Perak, Malaysia, nur.haziyanti@fsskj.upsi.edu.my

4 Widya Dharma University, English Education Department, Jl. Ki Hajar Dewantara, Klaten Utara, Klaten, Indonesia, didikrinan@unwidha.ac.id
}

Annotation. This study examines 290 elite athletes' stress on the training center, Indonesian National Sports Committee, Jawa Tengah. Self-rated questionnaire was used in this study, whilst data analysis used the IBM SPSS 20. Daily massive activity, interpersonal relationships, sense of self-loathing, and traumatic experience correlated to athletes' self-confidence and performance. This study addresses the competitiveness of athletes' self-esteem, positiveness, and constructiveness into peak performance.

Keywords: athletes' performance, sport training center, stress factors.

\section{Introduction}

Elite athletes' careers are professionally created from day-to-day high commitment, tight and rigid training schedules in which these will conditionally differ from differ individuals' capacity and position when they engaged in the training center program. Facing athletes' challenges in shaping their professional paths, coaches' roles are strongly involved in athletes' professionalism development, such as shaping elite athletes' experience and behaviors through the feedback provision (Carpentier \& Mageau, 2016), since 
sport regards the concept of developing athletes' mutual understanding, showing a sense of responsibility, and motivating them to be cooperative (Şekeroğlu, 2017). In this situation, elite athletes become more confident if they positively set up their cognitive-affective capacity (Zach et al., 2018).

Along with elite athletes' professionalism, sport circumstances take any consequences of athletes' attainment with the sufficient recovery and optimal highest performance. However, elite athletes will individually experience with the different sport circumstances and consequently matches with their strategies to gain the rhythm of relaxations (Pelka, 2017). Therefore, elite athletes' performance depends on the variety of their physiological and psychological determinants, such as genetics, fitness, skill, anxiety, and arousal with low or high levels of matches density which are influenced by the skilled competitors, poor fitness, illness, anxiety, stress, environmental situation (Rykert et al., 2017), and other intrinsic and extrinsic determinants.

Notwithstanding, some problems are recently still engaged in elite athletes' stress that leads to the crucial matter towards their performance achievement and resistance. This matter relatedly focuses on elite athletes' narrow, general anxiety, and escalated selfconsciousness (Nassib et al., 2019) during their training center program. Hamlin et al. (2019) believe that elite athletes' stress may be suddenly happened during their matches or sport trainings. The stress presence involves in both physiological and physical symptoms, such as stomachaches, muscles injury, sleeping disorders, and heart's irregular pulsation that are triggered by non-training environments and social pressure. This becomes the extreme pressure physically, such as frightening, intimidation, and excitement. Its sustainably leads to athletes' cognitive barriers in either breaking down tiredness or damaging to body's immunity system that may indicate athletes' mental failure (Eze, 2015), whereas the key principle for integrating life will harmonize the intended responses (Brajendra \& Rajesh, 2018) among athletes. Of these conditional efforts, elite athletes can afford the following steps to decrease their stress by working closer with practitioners, practicing their skills in non-hazardous conditions, examining self-efficacy in order to scan the stressfully non-sport environments (Hanton et al., 2009), and managing stressfulness in athletes' preparation, competition, and daily activities (Singh, 2017) with colleagues.

So far, elite athletes' stress is determined with any excitement source that straightly devastates psychological health's impacts, whilst stress can be indicative as a good or bad matter (Eze, 2015). Realizing elite athletes' stress categories, both dynamics and statics perspectives become fundamental that corresponds with the production of a volume load on the left ventricle, and emphasizes the production of a pressure load on the left ventricle within low, medium, and high levels towards athletes' stress intensity (Leddy \& Izzo, 2009). Being a relevant situation, Halladay (2013) attempt to portray athletes' life experience when stress is surrounded them with, 'I am bothered by how I feel, as if I am not sure how I am playing so I don't think I am helping my team and I am starting to get down on myself'. 
Some studies on elite athletes' stress factors confirmed their sports performance, management, and stress recovery. This helped them relieve pressure during their performance in training achievement programs. First, an over-stressed was influenced by overloading, burning out, dropping out, and developing maladaptive fatigue syndrome impacts toward athletes' mental health, such as perceptions of psychological, emotional, and behavioral issues in their training schemes (Singh, 2017). Second, Nassib et al. (2019) analysed the comparison of physical and psychological stress symptoms that showed the significant differences. Accordingly, they recorded a slight effect of symptom of muscle tension and main motivational effect. The physiological, mental, emotional, and existential ratings of psychological stress symptoms were to be consistent among athletes. Third, Finnemore (2017) emphasized that stress had been shown to adversely affect both psychological and physical health. Athletes with the chronic stress vulnerably tended to be risky with the severe health problems, such as rheumatoid arthritis, and cardiovascular disease as well as mental health issues, such as anxiety, depression, disordered eating, and alcohols and drugs addiction. Fourth, Rumbold et al. (2012) reinforced a number of stress reduction approaches became relevant if they were linked with athletes' increased stress awareness and improved results. The vulnerability impact of stress influenced the effectiveness of managing the stress itself. Lastly, athletes' awareness in any situation triggered the affective reactions proving the substance of mental toughness in recognizing the affective stress responses with the perceivably stress levels (Moen et al., 2019).

In accordance with Indonesian elite athletes' stress factors, this study proposes two research questions (RQs) in the following sports training center program: (1) Do elite athletes' stress factors influence their performance when following the sports training center program? (2) Can elite athletes' performance decrease some deficiencies as found in their stress factors? However, this study aims at examining elite athletes' performance upon their stress factors as found in the sport training center program at the Indonesian National Sports Committee (Komite Olahraga Nasional Indonesia), Jawa Tengah, Indonesia.

\section{Methods}

This study randomly carried out 290 of 356 Indonesian elite athletes from seven sport clusters at the Training Center Program of Indonesian National Sports Committee (Komite Olahraga Nasional Indonesia), Jawa Tengah, Indonesia. Athletes' age ranged in between 14 to 50 years old (Mage $=37.00 ; S D=32.52)$ when they fulfilled the questionnaire. The youngest respondent was a roller-skate athlete (14 years old) and the oldest one was a chess athlete (50 years old). Data collection used a simple random sampling technique. The collected data were carried out from self-rated questionnaire indicating elite athletes' stress factors as found in sport training center program. The scaling system was intentionally purposive with a 5-point Likert rubric to register athletes' mood 
ratings $(5=$ highly stressed, $4=$ stressed, $3=$ moderately stressed, $2=$ slightly stressed, $5=$ unstressed). This rubric was alterably adjusted through a rigorous content-validation process to modify all factors indication. The stress factors assessment covered four contributing distinction, such as the daily massive activity, interpersonal relationships, sense of self-loathing, and traumatic experiences.

These factors were firstly examined through the Cronbach's alpha reliability test engaging other thirty-seven elite athletes who engaged in the training center program at the Indonesian National Sports Committee, Jawa Tengah, Indonesia. The Cronbach's alpha internal consistency of athletes' stress factors derived from the following alpha $(\alpha)$ value: .778 for athletes' daily massive activity, .715 for athletes' interpersonal relationships, .740 for athletes' sense of self-loathing, and .759 for athletes' traumatic experiences. Meanwhile, the scale mean ranged from 2.977 to 4.324 with the overall value of alpha $(\alpha)=.799$. Data analysis used the SPSS program for analyzing the descriptive statistics, Pearson correlations, and factor analysis towards athletes' stress factors contribution. These analyses dealt with four distinguishable athletes' stress factors that perceived the principal components analysis with the Eigenvalue during the athletes joined in sport training center program. The statistics descriptive analyses contextually applied for the IBM SPSS software 20 to data processing.

\section{Results}

The descriptive analysis corresponded firstly with the daily massive activity of elite athletes in which the results of the descriptive and frequency statistics were shown as follows: 1 (.3\%) athlete was unstressed, 12 (4.1\%) athletes were marginally stressed, 91 (31.4\%) athletes were moderately stressed, 139 (47.9\%) athletes were stressed and $47(16.2 \%)$ athletes were extremely stressed as athletes spent several times with their everyday massive practice, either personal or professional. The result also recorded that $4.00(M=3.76$; $S D=.784 ; n=290$ ) obtained the highest Likert score of the average massive activity of athletes. The obtainable proof of the stress of athletes was bound to the frequency of 139 (47.9\%) at stressed stage. 


\section{Table 1}

Frequency on Elite Athletes' Daily Massive Activity

\begin{tabular}{lrrrr}
\hline Likert Scaling & Frequency & Percent & $\begin{array}{r}\text { Valid } \\
\text { Percent }\end{array}$ & $\begin{array}{r}\text { Cumulative } \\
\text { Percent }\end{array}$ \\
\hline 1.00 (Unstressed) & 1 & .3 & .3 & .3 \\
2.00 (Slightly stressed) & 12 & 4.1 & 4.1 & 4.5 \\
3.00 (Moderately stressed) & 91 & 31.4 & 31.4 & 35.9 \\
4.00 (Stressed) & 139 & 47.9 & 47.9 & 83.8 \\
5.00 (Highly stressed) & 47 & 16.2 & 16.2 & 100.0 \\
\multicolumn{1}{c}{ Total } & 290 & 100.0 & 100.0 & \\
& & & & \\
\hline
\end{tabular}

\section{Figure 1}

Histogram on Elite Athletes' Daily Massive Activity

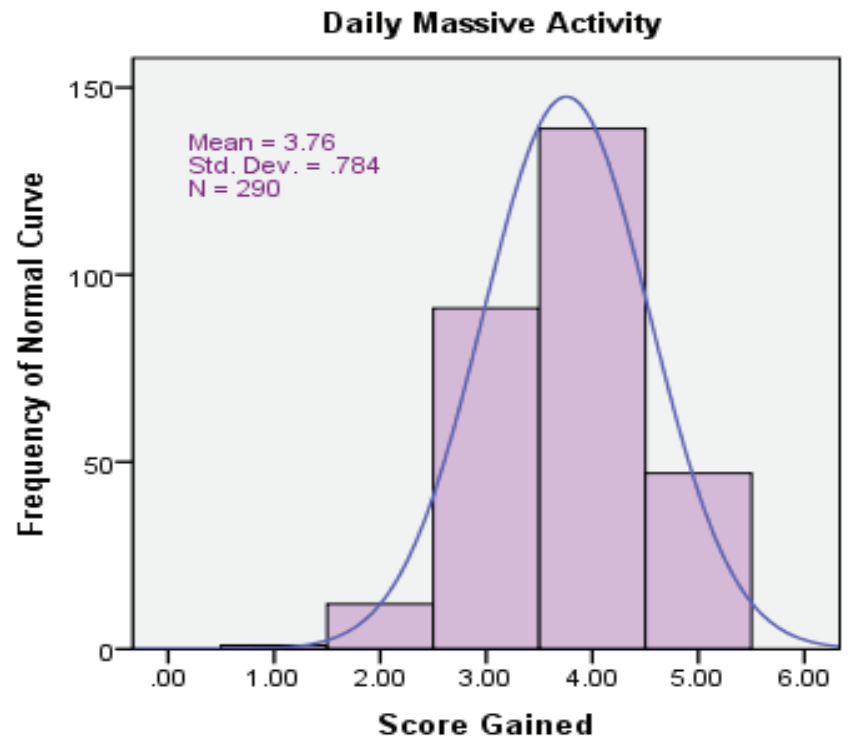

Note. Elite athletes' stress spent in daily massive practice both personal and professional life.

Secondly, the interpersonal relationships between elite athletes (Table 2 and Figure 2) showed that $5(1.7 \%)$ athletes perceived slight stress, 85 (29.3\%) were moderately stressed, 158 (54.5\%) were stressed, and 42 (14.5\%) were highly stressed when interpersonal relationships occurred. There was no athlete in this stress factor who perceived they were unstressed. The result also indicated Likert's highest score of interpersonal relationships among athletes was $4.00(M=3.82 ; S D=.689 ; n=290)$. The empirical proof of the stress of athletes was indicated with the frequency of $158(54.5 \%)$ in the stressed point. 
Table 2

Frequency on Elite Athletes' Interpersonal Relationships

\begin{tabular}{|c|c|c|c|c|}
\hline Likert Scaling & Frequency & Percent & $\begin{array}{r}\text { Valid } \\
\text { Percent }\end{array}$ & $\begin{array}{r}\text { Cumulative } \\
\text { Percent }\end{array}$ \\
\hline 2.00 (Slightly stressed) & 5 & 1.7 & 1.7 & 1.7 \\
\hline 3.00 (Moderately stressed) & 85 & 29.3 & 29.3 & 31.0 \\
\hline 4.00 (Stressed) & 158 & 54.5 & 54.5 & 85.5 \\
\hline 5.00 (Highly stressed) & 42 & 14.5 & 14.5 & 100.0 \\
\hline Total & 290 & 100.0 & 100.0 & \\
\hline
\end{tabular}

\section{Figure 2}

Histogram on Elite Athletes' Interpersonal Relationships

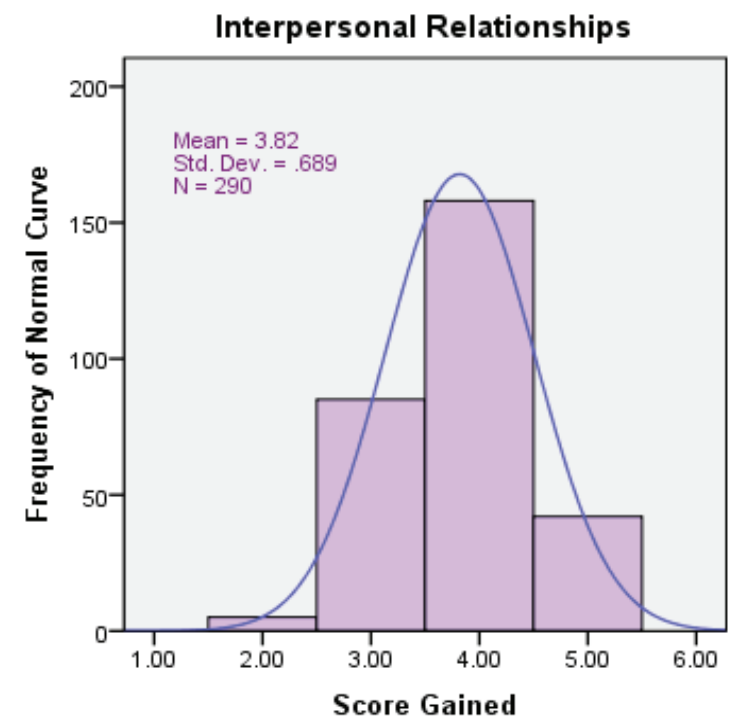

Note. Elite athletes' interpersonal relationships created self-confidence and supported performance successes in sport training program.

Thirdly, the sense of self-loathing analysis as shown in Table 3 Figure 3 mentioned in the following results: $6(2.1 \%)$ athletes were unstressed, $14(4.8 \%)$ athletes were mildly stressed, 53 (18.3\%) athletes were moderately stressed, 135 (46.6\%) athletes were stressed and $82(28.3 \%)$ athletes were extremely stressed while experiencing self-loathing. The result also verified that $4.00(M=3.94 ; S D=.919 ; n=290)$ was the highest level of athletes' sense of self-loathing. Empirical proof of the stress of athletes contributed to a stressed level at 135 frequency (46.6\%). 
Table 3

Frequency on Elite Athletes' Sense of Self-Loathing

\begin{tabular}{lllll}
\hline Likert Scaling & Frequency & Percent & $\begin{array}{l}\text { Valid } \\
\text { Percent }\end{array}$ & $\begin{array}{c}\text { Cumulative } \\
\text { Percent }\end{array}$ \\
\hline 1.00 (Unstressed) & 6 & 2.1 & 2.1 & 2.1 \\
2.00 (Slightly stressed) & 14 & 4.8 & 4.8 & 6.9 \\
3.00 (Moderately stressed) & 53 & 18.3 & 18.3 & 25.2 \\
4.00 (Stressed) & 135 & 46.6 & 46.6 & 71.7 \\
5.00 (Highly stressed) & 82 & 28.3 & 28.3 & 100.0 \\
Total & 290 & 100.0 & 100.0 & \\
& & & & \\
\hline
\end{tabular}

Figure 3

Histogram on Elite Athletes' Sense of Self-Loathing

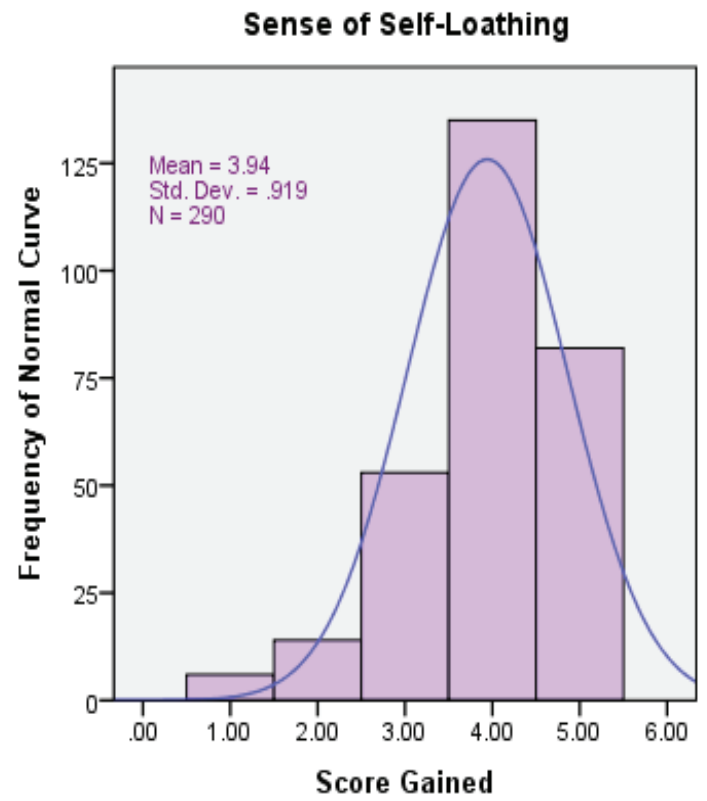

Note. Elite athletes' sense of self-loathing influenced cognitive functions, mental, and body control, as well as self-esteem and self-efficacy through the awareness of perseverance habits and life quality.

Fourthly, the study of traumatic experiences as shown in Table 4 and Figure 4 listed in the following results: $1(.3 \%)$ athlete was unstressed, $8(2.8 \%)$ athletes were mildly stressed, 87 (30.0\%) athletes were moderately stressed, 141 (48.6\%) athletes were stressed, 
and $53(18.3 \%)$ athletes were extremely stressed when they had the traumatic experiences in their competence. The result also stated that $4.00(M=3.82 ; S D=.77 ; n=290)$ received the highest score of traumatic encounters among athletes. Empirical evidence of stress by athletes led to a stressed level at $141(48.6 \%)$ frequency.

Table 4

Frequency on Elite Athletes' Traumatic Experiences

\begin{tabular}{lrrrr}
\hline Likert Scaling & Frequency & Percent & $\begin{array}{r}\text { Valid } \\
\text { Percent }\end{array}$ & $\begin{array}{r}\text { Cumulative } \\
\text { Percent }\end{array}$ \\
\hline 1.00 (Unstressed) & 1 & .3 & .3 & .3 \\
2.00 (Slightly stressed) & 8 & 2.8 & 2.8 & 3.1 \\
3.00 (Moderately stressed) & 87 & 30.0 & 30.0 & 33.1 \\
4.00 (Stressed) & 141 & 48.6 & 48.6 & 81.7 \\
5.00 (Highly stressed) & 53 & 18.3 & 18.3 & 100.0 \\
\multicolumn{1}{c}{ Total } & 290 & 100.0 & 100.0 & \\
& & & & \\
\end{tabular}

\section{Figure 4}

Histogram on Elite Athletes' Traumatic Experiences

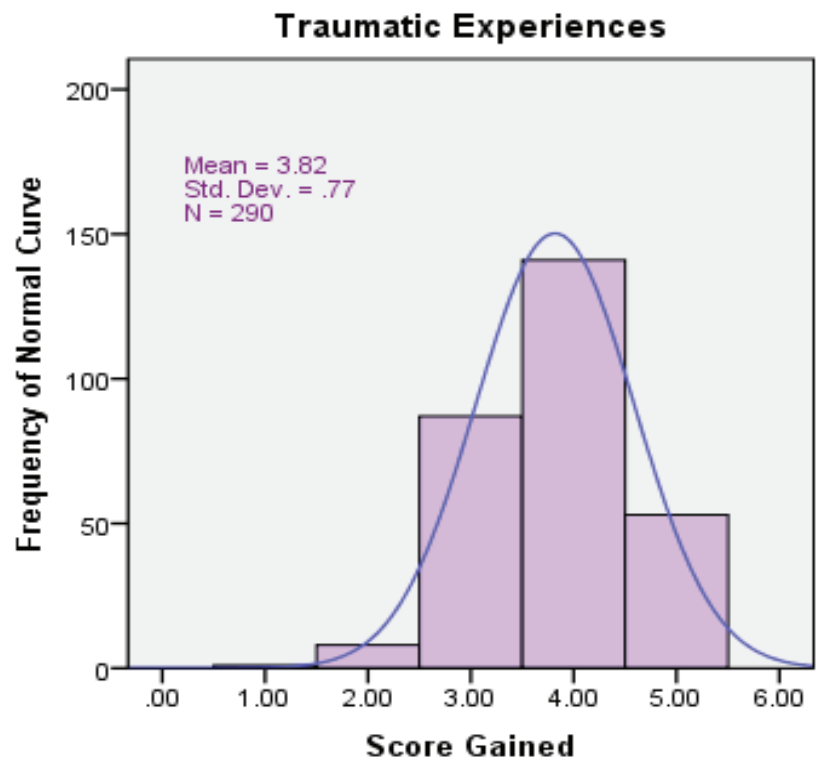

Note. Elite athletes' traumatic experiences might lead to a worse condition regarding physical activity. Muscle's balance and strength endured stability effectively during attending sport training sessions. 
Meanwhile, the success of Indonesian elite athletes in the training center program was consistent with their everyday activities. Table 5 explained these four stress factors (daily massive activity, interpersonal relationships, sense of self-loathing and traumatic experiences) in accordance with athletes' daily activity. This study accomplished 290 elite athletes in seven sport clusters who were professionally trained in Central Java Province's sport training center program, Indonesian National Sports Committee (Komite Olahraga Nasional Indonesia). The effects of descriptive data on stress factors for athletes were shown in the following summary: daily massive behavior $(M=3.75$; $S D=.783)$, interpersonal relationships $(M=3.81 ; S D=.689)$, sense of self-loathing $(M=3.94 ; S D=.918)$, and traumatic experiences $(M=3.81 ; S D=.769)$. The mean and standard deviation of this descriptive statistics was a 5-point-Likert scale for measuring the stress levels of athletes.

Further, the values of skewness and kurtosis were summarized among four variables as follows: daily massive behavior (-.233; -.090), interpersonal relationships (-.063; -.296), sense of self-loathing $(-.907 ; .897)$, and traumatic experiences $(-.224 ;-.086)$ were negligible to the success impact of athletes when engaging in the regular sport training center system. Of the values of skewness and kurtosis of athletes, the data were normal on condition. The lowest mean of stress factors for athletes, however, appointed daily massive activity $(M=3.75)$, while the highest mean of this factor was self-loathing $(M=3.94)$.

\section{Table 5}

Descriptive Statistics of Elite Athletes' Stress Factors

\begin{tabular}{|c|c|c|c|c|c|c|c|c|c|}
\hline \multirow{2}{*}{ Stress Factors } & \multirow{2}{*}{$\begin{array}{c}\mathrm{N} \\
\text { Statistic }\end{array}$} & \multirow{2}{*}{$\begin{array}{c}\text { Min. } \\
\text { Statistic }\end{array}$} & \multirow{2}{*}{$\begin{array}{c}\text { Max. } \\
\text { Statistic }\end{array}$} & \multirow{2}{*}{$\begin{array}{c}\text { Mean } \\
\text { Statistic }\end{array}$} & \multirow{2}{*}{$\begin{array}{c}\text { Std. Dev. } \\
\text { Statistic }\end{array}$} & \multicolumn{2}{|c|}{ Skewness } & \multicolumn{2}{|c|}{ Kurtosis } \\
\hline & & & & & & Statistic & Std. Error & Statistic & Std. Error \\
\hline Daily Massive Activity & 290 & 1.00 & 5.00 & 3.7552 & .78396 & -.233 & .143 & -.090 & .285 \\
\hline Interpersonal Relationships & 290 & 2.00 & 5.00 & 3.8172 & .68930 & -.063 & .143 & -.296 & .285 \\
\hline Sense of Self-Loathing & 290 & 1.00 & 5.00 & 3.9414 & .91886 & -.907 & .143 & .897 & .285 \\
\hline Traumatic Experiences & 290 & 1.00 & 5.00 & 3.8172 & .76992 & -.224 & .143 & -.086 & .285 \\
\hline Valid N (listwise) & 290 & & & & & & & & \\
\hline
\end{tabular}

Moreover, Pearson correlations analysis constituted with the relationships among four perceivable athletes' stress factors as shown in their daily training center performance. These perceivable factors were descriptively analyzed by the Pearson product-moment correlation coefficients. The significant correlations among these factors were significantly confirmed that $r=.345, n=290, p<.000$. The highest level of significance value of athletes' stress factors corresponded with athletes' sense of self-loathing $\left(.345^{* *}\right)$, meanwhile, the lowest stress factor was associated with athletes' traumatic experiences $\left(166^{* *}\right)$. Hence, the significance value among these four perceivable stress factors was correspondingly 
positive and significant with $p<.01$ level for 2 -tailed prediction. Table 6 comparably showed each stress factor's highest value, in the following orders: $.345^{\star *}, .338^{\star *}, .320^{\star *}$, and $.224^{*}$.

\section{Table 6}

Pearson Correlations Among Elite Athletes' Stress Factors

\begin{tabular}{|c|c|c|c|c|c|}
\hline Stress Factors & & $\begin{array}{r}\text { Daily Massive } \\
\text { Activity }\end{array}$ & $\begin{array}{l}\text { Interpersonal } \\
\text { Relationships }\end{array}$ & $\begin{array}{r}\text { Sense of Self- } \\
\text { Loathing }\end{array}$ & $\begin{array}{r}\text { Traumatic } \\
\text { Experiences }\end{array}$ \\
\hline \multirow{3}{*}{$\begin{array}{l}\text { Daily Massive } \\
\text { Activity }\end{array}$} & Pearson Correlation & 1 & $.320^{* * *}$ & $.345^{* *}$ & $.166^{* *}$ \\
\hline & Sig. (2-tailed) & & .000 & .009 & .004 \\
\hline & $\mathrm{N}$ & 290 & 290 & 290 & 290 \\
\hline \multirow{3}{*}{$\begin{array}{l}\text { Interpersonal } \\
\text { Relationships }\end{array}$} & Pearson Correlation & $.320 * *$ & 1 & $.338 * *$ & $.224 * *$ \\
\hline & Sig. (2-tailed) & .000 & & .000 & .000 \\
\hline & $\mathrm{N}$ & 290 & 290 & 290 & 290 \\
\hline \multirow{3}{*}{$\begin{array}{l}\text { Sense of Self- } \\
\text { Loathing }\end{array}$} & Pearson Correlation & $.345^{* * *}$ & $.338^{* * *}$ & 1 & $.141^{* *}$ \\
\hline & Sig. (2-tailed) & .000 & .000 & & .016 \\
\hline & $\mathrm{N}$ & 290 & 290 & 290 & 290 \\
\hline \multirow{3}{*}{$\begin{array}{l}\text { Traumatic } \\
\text { Experiences }\end{array}$} & Pearson Correlation & $.166^{* * *}$ & $.224^{* * *}$ & $.141^{* *}$ & 1 \\
\hline & Sig. (2-tailed) & .004 & .000 & .016 & \\
\hline & $\mathrm{N}$ & 290 & 290 & 290 & 290 \\
\hline
\end{tabular}

** Correlation is significant at the 0.01 level (2-tailed)

${ }^{*}$ Correlation is significant at the 0.05 level (2-tailed).

The factor analysis was used to be the data exploration in the principal components analysis (PCA) for stress factors. Hence, the interpretation should judge its empirical results rather than exploring fast and deep statistical engagements. In this part, four elite athletes' stress factors conveyed the PCA in order to accomplish the factor analysis. Ahead of confirming the first and second components, its felicitousness was examined to verify the obtainable data. The correlation matrix should show the coefficients availability of .107 and above. The correlation matrix of the Kaiser Meyer-Olkin (KMO) of sampling acceptability earned .674, driving to the expected value of .6 and the Bartlett's test of Sphericity proved $p=.000$, therefore the factor analysis was appropriate. Pointedly, the correlation matrix relied on the significance of statistics values and emphasized its correlation matrix factorability. In this finding, the PCA covered the existence of four stress factors with the Eigenvalue outrunning 1, was reasonably gauged by $1.789 \%, .896 \%$, $.673 \%$, and $.643 \%$ of the provided data accordingly (Table 7). Hence, the scree plot drove the fix description by assuring the stress factors. In this respect, the scree plot (Figure 5) was engaged in two disapproval axes for the further examination and identified by the parallel analyses. The scree plot also confirmed two axes with the Eigenvalue adjusting the criterion values for the deliberately effectuation into the accessible matrix data [4 stress factors $\mathrm{x} 290$ Indonesian elite athletes]. 
Table 7

Measurable Variances Undertaken From Elite Athletes' Stress Factors

\begin{tabular}{|c|c|c|c|c|c|c|c|}
\hline \multirow[t]{2}{*}{ Stress Factors } & \multicolumn{2}{|c|}{ Initial Eigenvalue } & \multicolumn{3}{|c|}{ Extraction Sums of Squared Loadings } & \multicolumn{2}{|c|}{$\begin{array}{c}\text { Rotation Sums of Squared } \\
\text { Loadings(a) }\end{array}$} \\
\hline & Total & $\%$ of Variance & Cumulative $\%$ & Total & $\%$ of Variance & Cumulative $\%$ & Total \\
\hline Daily Massive Activity & 1.789 & 44.715 & 44.715 & 1.789 & 44.715 & 44.715 & 1.267 \\
\hline Interpersonal Relationships & .896 & 22.398 & 67.113 & .896 & 22.398 & 67.113 & 1.098 \\
\hline Sense of Self-Loathing & .673 & 16.823 & 83.936 & .673 & 16.823 & 83.936 & 1.249 \\
\hline Traumatic Experiences & .643 & 16.064 & 100.000 & .643 & 16.064 & 100.000 & 1.253 \\
\hline
\end{tabular}

Extraction Method: Principal Component Analysis.

a. When components are correlated, sums of squared loadings cannot be added to obtain a total variance.

\section{Figure 5}

Scree Plot of Elite Athletes' Stress Factors

Scree Plot

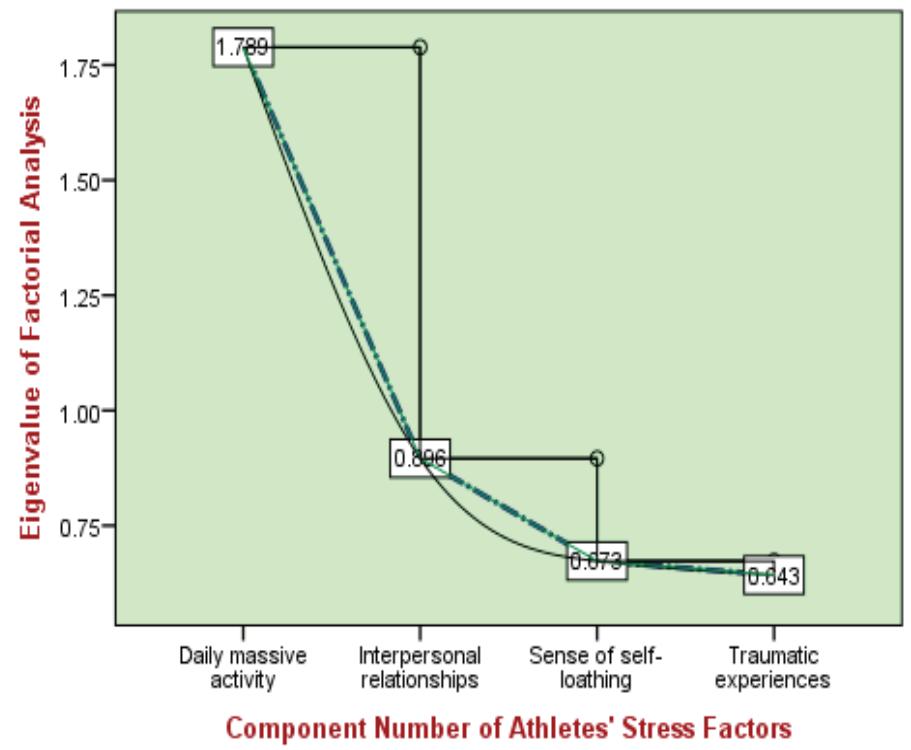

Note. Elite athletes' stress factors showed two disapproval axes for the further examination through the Eigenvalue that adjusted the criterion values for the deliberately effectuation into the accessible matrix data.

The factorial analysis (Table 7) remarked the first component with $44.715 \%$, whilst the second component was $22.398 \%$. Next, the oblimin rotation needed to validate the first and second components of factorial analysis. The rotated outputs showed the simple structure subsistence with either first or seconds components. These referred to the squared loadings numbers and four influential stress factors that indicated significantly on the first component. Further, the first and second components' description recorded the preliminary results of athletes' influential stress factors scale. Herein, the first component of pattern coefficients showed a positive value, whilst the second component only showed a positive value for the traumatic experiences and a negative value for the sense 
of self-loathing. Meanwhile, the first component of structure coefficients showed three positive values, except the sense of self-loathing and the second component of structure coefficients only recorded the sense of self-loathing as having a positive value. These values basically led to be the contrastive correlations between the first and second components (Table 8). Either the positive or negative values of the Eigenvalue derivation addressed its usability in the separate scales. Of this factorial analysis, the explanation of athletes' performance might be influential from their excessive exercise training, hedonic lifestyle, aversive stimulation, overload competition, fear of failure, sadness, anger, frustration, dissatisfaction, over targeting results, physical injuries, inconvenience, inability to filter rumors or hoaxes, and inflexible acceptance towards various climates. All these reasons potentially led to athletes' stress appearance in every performance.

\section{Table 8}

Pattern and Structure Matrix for PCA With the Oblimin Rotation of Two-Component of Stress Factors

\begin{tabular}{lccccc}
\hline \multirow{2}{*}{ Stress Factors } & \multicolumn{2}{c}{ Pattern coefficients } & \multicolumn{2}{c}{ Structure coefficients } & \multicolumn{2}{c}{ Communalities } \\
\cline { 2 - 6 } & $1^{\text {st }}$ Component & $2^{\text {nd }}$ Component & $1^{\text {st }}$ Component & $2^{\text {nd }}$ Component & \\
\hline Interpersonal Relationships &. $\mathbf{7 3 3}$ & $\mathrm{N} / \mathrm{A}$ & $\mathbf{1 . 0 0 0}$ & $\mathrm{N} / \mathrm{A}$ & 1.000 \\
Sense of Self-Loathing & .713 & -.332 & $\mathrm{~N} / \mathrm{A}$ & $\mathbf{1 . 0 0 0}$ & 1.000 \\
Daily Massive Activity &. $\mathbf{7 1 2}$ & $\mathrm{N} / \mathrm{A}$ & $\mathbf{3 2 0}$ & $\mathrm{N} / \mathrm{A}$ & 1.000 \\
Traumatic Experiences & $\mathbf{. 4 8 6}$ & $\mathbf{. 8 5 2}$ & $\mathbf{. 3 3 8}$ & $\mathrm{N} / \mathrm{A}$ & 1.000 \\
\hline
\end{tabular}

Note: major loadings for each item were in boldface; N/A = Non-Available

Of the overall analyses, this study realized to have limitations. The limitations firstly relied on the use of 'custom-tailored' self-rated questionnaire that was considered to be subjective by some athletes. Hence, this study suggested identifying some speculative fulfillment till the assertive validity and reliability testing were accurately examined. Secondly, the limitation accorded with the timely and questionnaire's fulfillment accuracy regarding athletes' eligibility that regarded any deviation from this practicality leading to the data corruption. Thirdly, respondents' characteristics, social modality, and entirely young physicality who engaged in the training center program might be influenced by their multiple academic, social, and economic status. Therefore, athletes' understanding regarding the questionnaire fulfillment might be merely applicable to this limited cohort and might not be generalizable.

\section{Discussion}

The discussion carried out of elite athletes' stress factors that became parts and arrays during joining in the sports training center program. All matters relating to athletes' stress factors were logically reflected from the cognitive processes that produced the emotional 
conditions and the periphery roles through the potential situations (Winarni \& Lutan, 2020). Elite athletes' stress factors highlighted the interpersonal relationships, sense of self-loathing, daily massive activity, and traumatic experiences. Firstly, the factor relied on elite athletes' interpersonal relationships that possibly supported personal and professional relationships among athletes, coaches, and other personal relatives. Rykert et al. (2017) supported that athletes, coaches, and other personal relatives might flexibly adopt any information relating to the training implementation. This information dealt with the appropriately assigned tasks for athletes, physical resources, and time management. Accordingly, the substantial prominence in athletes' interpersonal relationships relied on a good social interaction for giving and receiving supports from other teammates (Miçooğullari \& Kirazci, 2016). Elite athletes' interpersonal relationships undertake an important role to create self-confidence. Thereupon, athletes' self-confidence might support the performance successes in sport training program sessions beside controlling verbal and emotional engagement (Mulaosmanović et al., 2018), as well as maintaining meaningful efforts with verbal communication (Chakhachiro, 2016; Sumekto \& Setyawati, 2020). Athletes' self-confidence, according to Hanton et al. (2009) also corresponded with their physical and psychological capacity, weather, and environmental conditions that might impact athletes' different stress responses. The efforts of stress prevention might maximize self-confidence, performance, supports creation, communication among colleagues, relationships management (Faure \& Appleby, 2014). The interactive relationships between athletes' individual characteristics and cultures triggered the positive effects. The internal and external relationships were dynamic and changeable to support athletes' best timetable qualities (Chang et al., 2020). Athletes who could manage their time regularly were kept from the distraction distancing when the symptoms of stress relied on the physical problems (Nassib et al., 2019) within the interpersonal relationships.

The second factor explored a sense of self-loathing that conditionally influenced elite athletes' performance. The sport training performance influenced athletes' cognitive functions, mental, and body control (Brajendra \& Rajesh, 2018). Self-esteem and self-efficacy engaged in athletes' awareness of perseverance habits and life quality. Positive attitudes were at the first stage to recover since it would be the security in athletes' ability to be a critical moment, as well as physical participation that might improve mental health and self-esteem. When lacking of self-confidence, athletes would frequently decrease on the performance capacity, not be trustworthy, find the extremely useless boundaries (Mulaosmanović et al., 2018). Their introvert or extrovert personality might also influence the recovery periods of self-confidence beliefs which led to the poor performance effects (Beattie et al., 2010). Hence, elite athletes' intrinsic and extrinsic motivation should positively stimulate identification and introjection (Sari et al., 2015), and need to require from the pertinent parties to turn the motivational circumstance on surrounding them (Ibrahim et al., 2016), since athletes' physical and mental relaxation, and thoughts were available to recover under the remedial approaches (Hanton et al., 2009). Athletes' internal 
determinants potentially triggered to the perfectionism, pessimism, and introversion, whilst the external ones accordingly be impacted by the coaching system, team performance and communication, and socioeconomic capacity as well as athletes' individual behaviors that might bring about the culture variances (Chang et al., 2020).

The third factor corresponded with elite athletes' daily massive activity. This relied on athletes' training or competition routines that became the important aspects. So far, athletes' customary indicators, such as load factor, volume, rest interval, and exercise order dominantly influenced the efficiency, safety, and ultimate effectiveness of their training program (Simão et al., 2012). Unfortunately, elite athletes' activities were faced with both physical and psychological overloads that conveyed joy, satisfaction, pleasure, frustration, anger, and anxiety (Sumekto et al., 2020). In order to reduce the customary indicators, an appropriate training schedule should be well-prepared in order to avoid causing the factors to be happened again and again (Sallayici et al., 2018), beside doing the relaxation exercises would be a significant effect on sleep quality (Payami et al., 2018) and a positive effect of stretching on elite athletes' performance (Kabešová et al., 2019). Conversely, when elite athletes' performance got worse, others immediately began to say, 'What was a horrible match... They did not really play their potential'. No matter that it was not a good day or the athletes lacked of preparation and they just showed their nerves incidentally (Rykert et al., 2017). Shortly, athletes became overload and rapidly restored their focus on achieving the best performance (Gilbert et al., 2007). For the better anticipation, Nassib et al. (2019) agreed that one of the physiological changes carried on muscles' stress into the body kinesthesis. Fit muscles linked to the body more resilient to be mobile.

The fourth factor complied with elite athletes' traumatic experiences that might trigger their physics into a worse condition. Rusu et al. (2015) believed that most of physical activity required muscles balance and strength to endure stability. It was important to prepare a well-timed management, muscles' pre-activation, before a short and fast eccentric phase commencement, as well as an immediate transition between the eccentric and concentric phases of action effectively during attending the training sessions. The mechanical muscle processes focused on the elastic-explosive phases that could stimulate athletes' performance. To anticipate athletes' traumatic experiences became unmanageable that influenced their performance during joining in the training programs, Baçanac et al. (2014) confirmed that the impact of athletes' self-esteem highly affected the self-confidence, motivation increase, goal settings, and psychological readiness under pressure. The reasons were possible to befall when athletes were trapped in either aggressive or high-risk behaviours (Chang et al., 2020). The rigorousness of the depressive symptoms could be based on athletes' injuries, mobility limit, and length of rehabilitation. This condition was due to athletes' feeling socially isolated, opportunities loss, and accumulative absence from the training agenda (Sheinbein, 2016). Athletes' experience negative feelings, mood disturbance, loss, and isolation potentially lead to 
their traumatic experiences. Focusing on increasing motivation and self-confidence might promote rehabilitation to reduce fear and anxiety when they returned to the training sessions (Santi \& Pietrantoni, 2013).

Last but not least upon all elite athletes' stress factors regarded the mindfulness that was also important for training, competition, and during rest times. Self-kindness led to athletes' self-forgiveness for any inadequacies by understanding and reflecting the attitudes, re-evaluating situations, and moving forward with the positive mindset (Wilson et al., 2018), as well as indicating a greater positive effect on changes in athletes' fitness (Yerzhanova et al., 2020). Athletes' decision-making qualifications would depend on their behavior capacity and professional profiles (Kaya, 2014). The gifted talents and achievable performance were in line with athletes' force-time influence, general and specific sport skills, and muscular strengths. This condition involved athletes' training characteristics that potentiated to support the strength-power potentiation complexes, the magnitude of potentiation, and the reduction of injury risk (Suchomel et al., 2016).

\section{Conclusions}

Empirically Indonesian Elite athletes' stress factors can be traced from internal and external contributions that potentially influence their performance. All athletes' passion and endeavor daily supporting activities shall reflect the stress ranks which motivate the individual athletes to take decisions and actions. Athletes' stress factors when joining in sports training center program can be classified into low, middle, and high-excessive ranks. The experiences of having stresses stably address athletes' intentionally multiple experiences in the competitive situations towards their self-esteem challenges. The sports' stress management among athletes corresponds with how they cope, control, and reduce the deliverance of stress' negative existence towards their peak performance. The backgrounds of athletes' major stress factors lead to their positiveness and constructiveness of expecting the best performance.

As the consequences of facing this situation, athletes' daily massive activity, interpersonal relationships, sense of self-loathing, and traumatic experiences can be effectively reduced to increase their best performance. This conclusion provably and significantly stimulates athletes' self-confidence to obtain and to withstand the targeting achievements whilst joining in sports' training center program. Paying particular attention towards athletes shall be endorsed to control their habit of constructive ways, low and manageable physical and psychological stresses, to do with the flexibly imagery practices that address sticks, and to observe athletes' mental rehearsal continuity. 


\section{Acknowledgement}

The authors are grateful to Semarang State University, Indonesia for financing this research under Daftar Isian Pelaksanan Anggraran (DIPA) scheme in 2020.

\section{References}

Baĉanac, L., Milićević-Marinković, B., Kasum, G., \& Marinković, M. (2014). Competitive anxiety, self-confidence and psychological skills in top athletes with and without disabilities: A pilot study. Physical Education and Sport, 12(2), 59-70.

Beattie, S., Hardy, L., Savage, J., Woodman, T., \& Callow, N. (2010). Development and validation of a trait measure of robustness of self-confidence. Psychology of Sport and Exercise, 12(2), 184-191. doi: 10.1016/j.psychsport.2010.09.008

Brajendra, B., \& Rajesh, T. (2018). Stress management technique for athletes during sports: A critical review. Journal of Drug Delivery and Therapeutics, 8(5-s), 67-72. doi: 10.22270/jddt.v8i5-s.1956

Carpentier, J., \& Mageau, G. A. (2016). Predicting sport experience during training: The role of change-oriented feedback in athletes' motivation, self-confidence and needs satisfaction fluctuations. Journal of Sport \& Exercise Psychology, 38, 45-58. doi: 10.1123/jsep.2015-0210

Chakhachiro, R. (2016). Contribution of prosodic and paralinguistic cues to the translation of evidentiary audio recordings. Translation \& Interpreting, 8(2), 46-63. doi: 10.12807/ $\underline{\text { ti.108202.2016.a04 }}$

Chang, C. J., Putukian, M., Aerni, G., Diamond, A. B., Hong, E. S., Ingram, Y. M., Reardon, C. L., \& Wolanin, A. T. (2020). Mental health issues and psychological factors in athletes: Detection, management, effect on performance, and prevention: American medical society for sports medicine position statement-executive summary. British Journal of Sports Medicine, 54 (4), 216-220. doi: 10.1136/bjsports-2019-101583

Eze, W. U. (2015). The strategies for sports coach in managing stressful situations in sports competitions. International Journal of Current Research and Academic Review, 3(6), 298-304.

Faure, C., \& KM. Appleby, K. M. (2014). The logistical management of the organizational stress of elite "pipeline" athletes: Interventions of national performance directors in an Olympic year". The Journal of SPORT, 3(2), 139-183.

Finnemore, R. (2017). Perceptions of stress experienced by student-athletes in an education opportunity program. Counselor Education Capstone, 44, 1-29.

Gilbert, J. N., Gilbert, W., \& Morawski, C. (2007). Coaching strategies for helping adolescent athletes cope with stress". Journal of Physical Education, Recreation, \& Dance, 78(2), 13-24. doi: $10.1080 / 07303084.2007 .10597967$

Halladay, C. R. (2013). Fear offailure: An exploratory study of division III student-athletes. [Master of Science Thesis,] Graduate Program in Exercise and Sport Sciences, Ithaca College]. Ithaca, New York. 
Hamlin, M. J., Wilkes, D., Elliot, C. A., Lizamore, C. A., \& Kathiravel, Y. (2019). Monitoring training loads and perceived stress in young elite university athletes. Frontiers in Physiology, 10(34), 1-12. doi: 10.3389/fphys.2019.00034

Hanton, S., Thomas, O. \& Mellalieu, S. (2009) Management of competitive stress in elite sport', In B. Brewer. (Ed.), International Olympic Committee Sport Psychology handbook, pp. 30-42. London: Wiley.

Kabešová, H., Vaněčková, J., Tarantová, H., Heidler, J., \& Černá, L. (2019). The effects of the application of dynamic and PNF stretching on the explosive strength abilities of the lower limbs in warm-up in hockey and football athletes. TRENDS in Sport Sciences, 1(26), 33-39. doi: $\underline{10.23829 / T S S .2019 .26 .1}-\underline{5}$

Kaya, A. (2014). Decision making by coaches and athletes in sport. Procedia-Social and Behavioral Sciences, 152, 333-338. doi: 10.1016/j.sbspro.2014.09.205

Leddy, J. J., \& Izzo, J. (2009). Hypertension in athletes. Journal of Clinical Hypertension, 11(4), 226-233. doi: 10.1111/j.1751-7176.2009.00100.x

Miçooğullari, B. O., \& Kirazci, S. (2016). Effects of 6 weeks psychological skill training on team cohesion, self-confidence \& anxiety: A case of youth basketball players. Universal Journal of Educational Research, 4(12), 2761-2768. doi: 10.13189/ujer.2016.041210

Moen, F., Hrozanova, M., Stiles, T. C., \& Stenseng, F. (2019). Burnout and perceived performance among junior athletes-Associations with affective and cognitive components of stress. Sports, 7(171), 1-11. doi: 10.3390/sports7070171

Mulaosmanović, N., Velickovska, L. A., Selimović, H., Hajder, M., Džibrić, D., Hrnjić, J. (2018). Aspects of self-confidence among young people engaged in sport activities. Research in Physical Education, Sport and Health, 7(2), 7-11.

Nassib, S. H., Mkaouer, B., Riahi, S. H., Wali, S. M., \& Nassib, S. (2019). The potential effects of relevant symptoms perceived by athletes and coping strategies upon athletics performance in competitive sport events. Journal of Psychological \& Clinical Psychiatry, 10(6), 213-219. doi: 10.15406/jpcpy.2019.10.00656

Pelka, M. (2017). Psychological relaxation techniques in sports: The acute effects of relaxation techniques between physical tasks. Kumulative Dissertation zur Erlangung des akademischen Grades eines Doktors der Philosophie (Dr. Phil.) im Fach Sport psychologie [Cumulative dissertation to obtain the academic degree of Doctor of Philosophy (Dr. Phil) in Sports Psychology]. Bochum: Fakultät für Sportwissenschaft, Ruhr-Universität Bochum.

Payami, H., Shojaeie, M., \& Sanatkaran, A. (2018). The effects of relaxation exercises on sleep quality and content of athlete's dreams at night before the competition. International Journal of Ecosystems and Ecology Science (IJEES), 8(1), 81-88.

Rumbold, J. L., Fletcher, D., \& Daniels, K. (2012). A systematic review of stress management interventions with sport performers. Sport, Exercise, and Performance Psychology, 1(3), 173-193. doi: $10.1037 / \mathrm{a} 0026628$

Rusu, L., Cosma, G., Calina, M. L., Dragomir, M. M., \& Marin, M. (2015). Evaluation of two muscle training programs by assessment of the muscle tone. Science \& Sports, 30(4), 179-244. doi: $10.1016 /$ j.scispo.2015.05.005 
Rykert, D., Harris, C., Adams, K. J., \& De Beliso, M._(2017)._Effect of spotters on state anxiety and self-confidence during maximal squatting among male high school athletes. Turkish Journal of Kinesiology, 3(3), 37-42.

Sallayici, M., Kolayiş, I. E., Kesilmiş, I., \& Kesilmiş, M. M. (2018). Examination of athletes' anxiety, motivation, imagination value in competitions with different severity level. Asian Journal of Education and Training, 4(1), 9-12. doi: 10.20448/journal.522.2018.41.9.12

Santi, G., \& Pietrantoni, L. (2013). Psychology of sport injury rehabilitation: a review of models and interventions. Journal of Human Sport \& Exercise, 8(4), 1029-1044. doi: 10.4100/jhse.2013.84.13

Sari, I., Ekici, S., Soyer, F., \& Eskiler, E. (2015). Does self-confidence link to motivation? A study in field Hockey athletes. Journal of Human Sport \& Exercise, 10(1), 24-35. doi: 10.14198/ jhse.2015.101.03

Şekeroğlu, M._Ö. (2017). Study of the concepts of athletic identity and continuous sport selfconfidence in the light of various variables. Journal of Education and Training Studies, 5(13), 44-51. doi: 10.11114/jets.v5i13.2901

Sheinbein, R. (2016). Psychological effect of injury on the athlete: A recommendation for psychological intervention. AMAA Journal Fall/Winter, 8-10.

Simão, R., de Salles, B. F., Figueiredo, T., Dias, I., \& Willardson, J. M. (2012). Exercise order in resistance training. Sports Medicine, 42(3), 1-15. doi: 10.2165/11597240-000000000-00000

Singh, R. (2017). Stress role in sports performance of athletes. International Journal of Physical Education, Sports and Health, 4(3), 278-280.

Suchomel, T. J., Nimphius, S., \& Stone, M. H. (2016). The importance of muscular strength in athletic performance. Sports Medicine, 46, 1419-1449. doi: 10.1007/s40279-016-0486-0

Sumekto, D. R., Setyawati, H., Tukiyo \& Warsito, R. (2020). The determinants of lecturers' classroom management as depicted in their teaching performance. Pedagogika, 139(3), 136-156. doi: 10.15823/p.2020.139.7

Sumekto, D. R., \& Setyawati, H. 2020. Revealing lecturer's paralinguistic attribution: How the visual manner contributes to students' non-cognitive skills. Indonesian Journal of Applied Linguistics, 9(3), 559-571. doi: 10.17509/ijal.v9i3.23206

Wilson, C., Bennett, R. V., Mosewich, A. D., Faulkner, G. E., \& Crocker, P. R. E. (2018). The zipper effect: Exploring the interrelationship of mental toughness and self-compassion among Canadian elite women athletes. Psychology of Sport \& Exercise, 40, 61-70. doi: 10.1016/j. psychsport.2018.09.006

Winarni, S., \& Lutan, R. (2020). Empathy and tolerance in physical education: Cooperative vs. classical learning. Cakrawala Pendidikan, 39(2), 332-345. doi: https://doi.org/10.21831/cp.v39i2.31851

Yerzhanova, Y., Madiyeva, G., Sabyrbek, Z., Dilmakhambetov, E., \& Milašius, K. (2020). Can a high-energy diet affect the physical fitness of elite athletes? Pedagogika, 139(3), 239-252. doi: $10.15823 /$ p.2020.139.12

Zach, S., Dobersek, U., Filho, E., Inglis, V., \& Tenenbaum, G. (2018). A meta-analysis of mental imagery effects on post-injury functional mobility, perceived pain, and self-efficacy. Psychology of Sport and Exercise, 34, 79-87. doi: 10.1016/j.psychsport.2017.09.011 


\title{
Empirinis elito sportininkų, dalyvaujančių sporto mokymo centro programoje, streso veiksnių tyrimas
}

\author{
Heny Setyawati ${ }^{1}$, Tandiyo Rahayu ${ }^{2}$, Nur Haziyanti binti Mohamad Khalid ${ }^{3}$, Didik Rinan Sumekto ${ }^{4}$ \\ Semarango valstybinis universitetas, Kūno kultūros katedra, F1 pastatas, Sekaranas, Semarangas, Indonezija, \\ henysetyawati@mail.unnes.ac.id \\ 2 Semarango valstybinis universitetas Kūno kultūros katedra, F1 pastatas, Sekaranas, Semarangas, Indonezija, \\ tandiyorahayu@mail.unnes.ac.id \\ 3 Sultono Idriso švietimo universitetas, Sporto mokslo ir treniravimo katedra, Jalan Slim, MY-35900 Tanjong \\ Malimas, Perakas, Malaizija, nur.haziyanti@fsskj.upsi.edu.my \\ 4 Widya Dharma universitetas, Anglų kalbos katedra, Jl. Ki Hajaras Dewantara, Klaten Utara, Klatenas, Indonezija, \\ didikrinan@unwidha.ac.id
}

\section{Santrauka}

Geriausių sportininkų karjera yra profesionaliai sukurta atsižvelgiant ị didžiulị atsidavimą sportui, ịtemptus ir griežtus treniruočių grafikus. Visa tai sukuria jiems palankią situaciją ir sudaro išskirtines galimybes, dalyvaujant sporto mokymo centro programoje.

Siekiant įveikti sportininkų iššūkius, formuojant jų profesinius kelius, trenerių pareiga rūpintis sportininkų profesionalumu. Šiuo tyrimu siekiama ištirti geriausių sportininkų rezultatus atsižvelgiant i jų streso veiksnius, kaip nustatyta sporto mokymo centro programoje Indonezijos nacionaliniame sporto komitete, Centrineje Javoje, Indonezijoje. Iš viso dalyvavo 290 geriausių sportininkų iš septynių sporto sričių. Duomenys buvo renkami naudojant klausimyną pagal 5 balų Likerto skalę; SPSS programa, analizuojanti aprašomąją statistiką, buvo pasirinkta Pearsono koreliacijų ir streso veiksnių analizei remiantis geriausių sportininkų duomenimis.

Geriausių sportininkų streso veiksnius atitinkamai sudarè kasdienis intensyvus aktyvumas, tarpusavio santykiai, savigraužos jausmas ir traumuojanti patirtis. Tačiau šiame tyrime nagrinejjama daugybė geriausių sportininkų patiriamų problemų, susijusių su konkurencingais savivertès iššūkiais, tokiais kaip pozityvumas ir konstruktyvumas, tad norint pasiekti aukščiausią rezultatą reikia pasitelkti lanksčią praktiką, kuri padeda ištverti bei periodiškai stebėti sportininkų psichologinę būklę. Nustatyta, kad kasdieninè intensyvi veikla, tarpusavio santykiai, savigraužos jausmas ir traumuojanti patirtis koreliuoja su sportininkų pasitikejimu savimi ir rezultatais.

Esminiai žodžiai: sportininku pasirodymas, sporto mokymo centras, streso veiksniai. 